\title{
Editorial
}

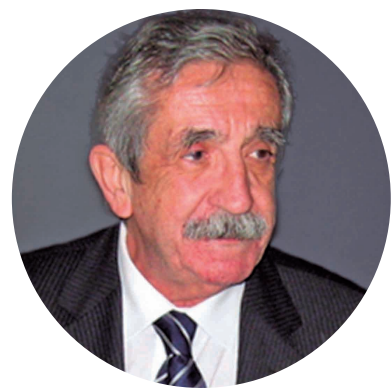

RAMÓN VILADOT-PERICÉ

SPAIN

PAST - PRESIDENT OF THE SPANISH

SOCIETY OF FOOT AND ANKLE SURGERY AND MEDICINE (SOCIEDAD ESPAÑOLA DE MEDICINA Y CIRUGIA

DEL PIE Y TOBILLO, SEMCPT).

PAST - PRESIDENT OF THE COLLĖGE INTERNATIONAL DE PODOLOGIE (CIP), (PREDECESSOR OF THE CURRENT INTERNATIONAL FEDERATION OF FOOT \& ANKLE SOCIETIES, IFFAS).

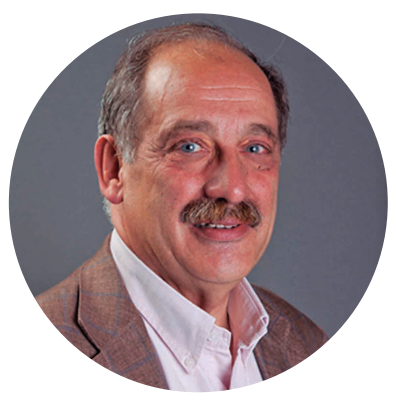

ANTONIO VILADOT VOEGELI

SPAIN

PAST - PRESIDENT OF THE SPANISH SOCIETY OF FOOT AND ANKLE SURGERY AND MEDICINE (SOCIEDAD ESPAÑOLA DE MEDICINA Y CIRUGIA DEL PIE Y TOBILLO, SEMCPT). PAST - PRESIDENT OF THE EUROPEAN FOOT ANKLE SOCIETY (EFAS).

\section{What is new about hallux rigidus?}

Hallux rigidus (HR) represents one of the most frequent forefoot disorders, together with hallux valgus and lateral toe deformities, being the most frequent degenerative process in the foot and ankle.

This publication is the result of the collaboration of colleagues of the Spanish Society of Medicine and Foot and Ankle Surgery (Sociedad Española de Medicina y Cirugía del Pie y Tobillo, SEMCPT) and the Argentinean Society of Medicine and Foot and Leg Surgery (Sociedad Argentina de Medicina y Cirugía de Pie y Pierna, SAMCPP). It is an honor for us to have this work edited in the Journal of the Foot \& Ankle, a journal with a marked Latin identity. We really thank Alexandre Leme Godoy-Santos, Chairman of the Editorial Board, for his help and contribution. This update topic has been coordinated by $R$. Viladot Pericé and A. Viladot Voegeli, together with M. Herrera and M. Núñez-Samper.

Considering the interest and the extent of this topic and, according to the coordinators, we have divided the publication into two parts. The first one describes general aspects (definition, etiology, classification, treatment algorithm, etc.) and the conservative treatment of HR, whereas the second one addresses the different surgical techniques described to treat this disease.

The aim of this work is to review our knowledge on HR and to perform an update on the innovations that have emerged during the last years. 


\section{The Journal of the Foot \& Ankle (eISSN 2675-2980) is}

published quarterly in April, August, and December, with the purpose of disseminating papers on themes of Foot and Ankle Medicine and Surgery and related areas. The Journal offers free and open access to your content on our website. All papers are already published with active DOls.

\section{ASSOCIATED SOCIETIES}

\section{Argentina}

Sociedad Argentina de Medicina y Cirugía de Pie y Pierna http://www.samecipp.org.ar/

\section{Bolivia}

Sociedad Boliviana de Medicina y Cirugía del Tobillo y Pie http://www.sbolot.org/

\section{Brazil}

Brazilian Association of Medicine and Surgery of the Ankle and Foot http://www.abtpe.org.br/

\section{Chile}

Comité de Tobillo y Pie de la Sociedad Chilena de Ortopedia y Traumatologia (SCHOT)

http://www.schot.cl/

\section{Colombia}

Capítulo de Pie y Tobillo de la Sociedad Colombiana de Cirugía Ortopedia y Traumatología (SCCOT)

http://www.sccot.org.co/

\section{Mexico}

Sociedad Mexicana de Pie y Tobillo https://www.facebook.com/smpieytobillo/

\section{Peru}

Capítulo Peruano de Cirugía del Pie y Tobillo (CAPPiTO) - Sociedad Peruana de Оyт

http://www.spotrauma.org/

\section{Portugal}

Sociedade Portuguesa de Ortopedia e Traumatologia (SPOT)

http://www.spot.pt/

\section{Uruguay}

Sociedad de Ortopedia y Traumatologia del Uruguay - Comité Uruguayo de Estudios del Pie (CUEP)

http://wwwisotu.org.uy//

\section{Venezuela:}

Cápítulo de Tobillo y pie de la Sociedad Vênezolana de cirugiáa ôrtopédica y Traumátọlogía (SVCOT)

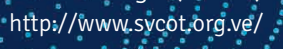

\section{Follow us}

This and other publications are available at (4) https://jfootankle.com/JournalFootAnkle/index or by QR Code:

\section{@journalofthefootandankle}

(-) https://jfootankle com/JournalFootAnkle

Djfootankle@jfootankle.com 